\title{
Prediction of Stock Market using Data Mining and Artificial Intelligence
}

\author{
G. S. Navale \\ Savitribai Phule Pune \\ University \\ SITS Narhe, Pune-411041
}

\author{
Nishant Dudhwala \\ Savitribai Phule Pune \\ University \\ SITS Narhe, Pune-411041
}

\author{
Kunal Jadhav \\ Savitribai Phule Pune \\ University \\ SITS Narhe, Pune-411041
}

\author{
Pawan Gabda \\ Savitribai Phule Pune University \\ SITS Narhe, Pune-411041
}

\author{
Brij Kishor Vihangam \\ Savitribai Phule Pune University \\ SITS Narhe, Pune-411041
}

\begin{abstract}
Predicting anything is very hard where the relationship between inputs and outputs are non-linear in nature. The prediction of stock market values is one of a challenging task of financial time series. Online application for buying and selling the shares is used in high amounts these days. The next step of this web application will be not just registering, buying and selling the shares but it will also be predicting the values for particular shares in the market. We are proposing the system which will study the database of shares and will give predictions according to it. With the help of study of neural networks the system will be designed and based on. For prediction particularly ARMA (autoregressive-movingaverage) algorithm is used. Hence the system will be able to give highest probability predictions for particular shares.
\end{abstract}

\section{General Terms}

Data Mining, Prediction, Stock Market

\section{Keywords}

Artificial Neural Network, ARMA Algorithm, News articles, Text mining

\section{INTRODUCTION}

Data mining is analytic process design to explore data (usually large amount of data-typically business or market related- also known as "Big Data") in search of consistent patterns and/or systematic relationships between variables, and then to validate the findings by applying the detected patterns to new.

Stock market is very volatile in nature. Prices of stocks changes almost instantly. Financial analysts who purchases stocks are not aware of all factors like inflation, economic growth affecting stocks prices. They do not have idea in which stocks to invest and sell. They can be easily manipulated by the stock brokers. Stock prices depend on news appearing in news articles. It is not possible for an average buyer to analyze such large amount of information .To deal with this problem Data Mining technique can be used. Data mining can automatically extract important information from large amount of data that is affecting the stock prices [9].

Predicting the stocks prices accurately can be done by Artificial Neural Network (ANN). The advantage of using ANN is that it can deal with both linear and non-linear data for forecasting the stock prices. Network is set of interconnected nodes and a node is a computational unit which produces an output on receiving an input. The nodes can be both unidirectional and bidirectional. In unidirectional nodes, information can flow in one way while in bidirectional nodes, information can flow in both ways. So, ANN is neural network consisting of artificial neurons. ANN is inspired by the way our brain functions [10].

\section{RELATED WORK}

Table 1

\begin{tabular}{|c|c|c|c|}
\hline $\begin{array}{c}\text { Paper } \\
\text { ID }\end{array}$ & Methodology & Advantage & Disadvantage \\
\hline [1] & $\begin{array}{l}\text { Genetic } \\
\text { Algorithm, } \\
\text { Support vector } \\
\text { machines. }\end{array}$ & $\begin{array}{l}\text { SVM } \\
\text { transform the } \\
\text { inputs into } \\
\text { decision } \\
\text { classes. } \\
\text { There is } \\
\text { correlation } \\
\text { between prices } \\
\text { of certain } \\
\text { stocks. } \\
\text { Considering } \\
\text { closing, } \\
\text { opening, mean, } \\
\text { standard } \\
\text { deviation and } \\
\text { number of days } \\
\text { for which } \\
\text { correlation is } \\
\text { found is } \\
\text { considered }\end{array}$ & $\begin{array}{l}\text { Various } \\
\text { political, } \\
\text { economic } \\
\text { factors, } \\
\text { company } \\
\text { policy decide } \\
\text { trends of } \\
\text { markets are } \\
\text { not } \\
\text { considered } \\
\text { while } \\
\text { calculation. }\end{array}$ \\
\hline [2] & $\begin{array}{l}\text { Sentiment } \\
\text { Analysis, } \\
\text { Trading model. }\end{array}$ & $\begin{array}{l}\text { They collected } \\
\text { aggregating } \\
\text { information } \\
\text { from multiple } \\
\text { online sources. } \\
\text { They } \\
\text { performed } \\
\text { sentiment } \\
\text { analysis on } \\
\text { given data and } \\
\text { filtered out } \\
\text { dataset as a }\end{array}$ & $\begin{array}{l}\text { It is necessary } \\
\text { to analyze } \\
\text { effects of } \\
\text { applying } \\
\text { different } \\
\text { sentiments } \\
\text { analysis } \\
\text { methodology. }\end{array}$ \\
\hline
\end{tabular}




\begin{tabular}{|c|c|c|c|}
\hline & & $\begin{array}{l}\text { result of } \\
\text { sentiment } \\
\text { analysis and } \\
\text { they found the } \\
\text { ratio of } \\
\text { sentimental } \\
\text { signals. } \\
\text { Based on this, } \\
\text { they created on } \\
\text { trading model } \\
\text { to predict stock } \\
\text { prices and } \\
\text { trend of } \\
\text { market. }\end{array}$ & \\
\hline [3] & $\begin{array}{l}\text { ANN(artificial } \\
\text { neural } \\
\text { network), } \\
\text { Back- } \\
\text { propagation } \\
\text { algorithm }\end{array}$ & $\begin{array}{l}\text { It can be used } \\
\text { in field where } \\
\text { accurate } \\
\text { mathematical } \\
\text { model cannot } \\
\text { be produced, } \\
\text { for example } \\
\text { stock market } \\
\text { It can deal with } \\
\text { noisy data. }\end{array}$ & $\begin{array}{l}\text { Designing is } \\
\text { challenging as } \\
\text { it requires } \\
\text { tedious trial } \\
\text { and error } \\
\text { process. } \\
\text { Selection of } \\
\text { data set is } \\
\text { complex. }\end{array}$ \\
\hline [4] & $\begin{array}{l}\text { Linear } \\
\text { regression, } \\
\text { Data mining. }\end{array}$ & $\begin{array}{l}\text { Linear } \\
\text { regression is } \\
\text { used to } \\
\text { perform } \\
\text { operation data } \\
\text { set where } \\
\text { target values. } \\
\text { It establishes } \\
\text { relation } \\
\text { between target } \\
\text { values and } \\
\text { predicted } \\
\text { values. } \\
\text { Data mining } \\
\text { technique have } \\
\text { more } \\
\text { successful } \\
\text { performance in } \\
\text { predicting } \\
\text { various fields } \\
\text { as it uses } \\
\text { hidden } \\
\text { knowledge of } \\
\text { data. }\end{array}$ & $\begin{array}{l}\text { Calculations } \\
\text { using linear } \\
\text { regression are } \\
\text { very complex. } \\
\text { In linear } \\
\text { regression, } \\
\text { Accuracy is } \\
\text { low. }\end{array}$ \\
\hline [5] & $\begin{array}{l}\text { Linear } \\
\text { regression, } \\
\text { Neural } \\
\text { networks, } \\
\text { Genetic }\end{array}$ & $\begin{array}{l}\text { It is used to } \\
\text { find accurate } \\
\text { results among } \\
\text { them. } \\
\text { Helpful for } \\
\text { gathering } \\
\text { financial data. }\end{array}$ & $\begin{array}{l}\text { Depend on } \\
\text { sentiments } \\
\text { and opinion } \\
\text { over news } \\
\text { content and }\end{array}$ \\
\hline
\end{tabular}

\begin{tabular}{|c|c|c|c|}
\hline & $\begin{array}{l}\text { Algorithm, } \\
\text { Support Vector } \\
\text { Machine, } \\
\text { Case based } \\
\text { reasoning. }\end{array}$ & $\begin{array}{l}\text { They are } \\
\text { helpful to map } \\
\text { the relations } \\
\text { among } \\
\text { financial } \\
\text { product and } \\
\text { financial news. }\end{array}$ & global events. \\
\hline [6] & $\begin{array}{l}\text { Typical price, } \\
\text { Chwkin money } \\
\text { flow indicator, } \\
\text { Relative } \\
\text { Strength Index. }\end{array}$ & $\begin{array}{l}\text { It calculates the } \\
\text { high, low and } \\
\text { close value of } \\
\text { the market. } \\
\text { Also, it tends } \\
\text { to give mid } \\
\text { value so that } \\
\text { customer can } \\
\text { buy and sell } \\
\text { share } \\
\text { according to } \\
\text { the values } \\
\text { given }\end{array}$ & $\begin{array}{l}\text { Problem is } \\
\text { determining } \\
\text { the } \\
\text { probability } \\
\text { that the } \\
\text { relationships } \\
\text { are not } \\
\text { random at all } \\
\text { market } \\
\text { condition }\end{array}$ \\
\hline [7] & $\begin{array}{l}\text { Data } \\
\text { collection, } \\
\text { Feed-forward } \\
\text { neural network. }\end{array}$ & $\begin{array}{l}\text { Several } \\
\text { machine } \\
\text { learning } \\
\text { techniques are } \\
\text { used in parallel } \\
\text { to predict most } \\
\text { optimal stock } \\
\text { market price. } \\
\text { The main } \\
\text { advantage is } \\
\text { that it provide } \\
\text { a very } \\
\text { systematic } \\
\text { approach and } \\
\text { its ability to } \\
\text { predict changes } \\
\text { before they } \\
\text { show up on the } \\
\text { chart. }\end{array}$ & 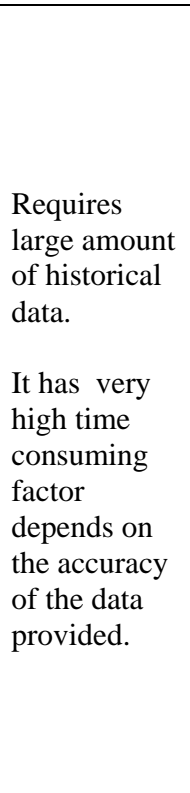 \\
\hline [8] & $\begin{array}{l}\text { NewsCAT, } \\
\text { Text } \\
\text { preprocessing, } \\
\text { Automatic text } \\
\text { categorization. }\end{array}$ & $\begin{array}{l}\text { It } \\
\text { automatically } \\
\text { analyzes and } \\
\text { categorizes } \\
\text { press releases } \\
\text { derive stock } \\
\text { trading } \\
\text { recommendatio } \\
\text { n from them. } \\
\text { It can } \\
\text { significantly } \\
\text { outperform old } \\
\text { trading } \\
\text { strategies like } \\
\text { buying and }\end{array}$ & $\begin{array}{l}\text { Selection of } \\
\text { categorization } \\
\text { is poor. } \\
\text { NewsCAT } \\
\text { engine needs } \\
\text { to be } \\
\text { enhanced. }\end{array}$ \\
\hline
\end{tabular}




\begin{tabular}{|c|c|c|c|}
\hline & & $\begin{array}{l}\text { shorting stocks } \\
\text { randomly } \\
\text { immediately } \\
\text { after press } \\
\text { release. }\end{array}$ & \\
\hline [9] & Data Mining. & $\begin{array}{l}\text { It helps to find } \\
\text { hidden pattern } \\
\text { in from historic } \\
\text { data that have } \\
\text { probable } \\
\text { predictive } \\
\text { capability. } \\
\text { It uses real } \\
\text { time news to } \\
\text { predict its } \\
\text { effect on } \\
\text { stocks. }\end{array}$ & $\begin{array}{l}\text { It requires } \\
\text { large amount } \\
\text { of historic } \\
\text { data. } \\
\text { Large amount } \\
\text { of data } \\
\text { processing is } \\
\text { required. }\end{array}$ \\
\hline [10] & $\begin{array}{l}\text { Artificial } \\
\text { neural } \\
\text { network(ANN) }\end{array}$ & $\begin{array}{l}\text { It helps to } \\
\text { build relation } \\
\text { between non- } \\
\text { linear input and } \\
\text { output. } \\
\text { It is very } \\
\text { intelligent } \\
\text { system and } \\
\text { works like } \\
\text { human brain. }\end{array}$ & $\begin{array}{l}\text { ANN have } \\
\text { not been fully } \\
\text { explored. } \\
\text { Prediction is } \\
\text { satisfactory } \\
\text { but still lot of } \\
\text { improvement } \\
\text { is needed. }\end{array}$ \\
\hline
\end{tabular}

\section{CONCLUSION}

By using data mining and artificial intelligence, we can get accurate prediction result. Most of the authors have used methodologies in artificial intelligence to achieve accuracy and performance as shown Table 1 . Still there is a need to improve the parameters accuracy and performance. This can be achieved with the help of Data Mining. Data Mining and Artificial Intelligence when put together will result in nearly accurate accuracy. The drawbacks of the other methodologies can be addressed by collaborating Artificial Intelligence and Data Mining. Investors gets an idea where to invest their valuable money.

\section{REFERENCES}

[1] Rohit Choudhry, Kumkum Garg, "A Hybrid Machine Learning System for Stock Market Forecasting" in International Journal of Computer, Electrical,
Automation, Control and Information Engineering Vol:2,No:3,2008

[2] Nann,Stefan , Krauss, Jonas, Schoder, Detlef , "Predictive Analytics on Public Data-The Case of Stock Markets" in the $21^{\text {st }}$ European conference on Information Systems.

[3] Manjul Saini, A.K.Singh, “ Forecasting Stock Exchange Market and Weather Using Soft Computing" in International Journal of Advanced Research in Computer Science and Software Engineering.ISSN:2277 128x, Volume 4,Issue 5,May 2014.

[4] Farhad Soleimanian Gharehchopogh, Tahmineh Haddadi Bonab, Seyyed Reza Khaze, " A LINEAR REGRESSION APPROACH TO PREDICTION OF STOCK MARKET TRADING VOLUME: A CASE STUDY" in International Journal of Managing Value and Supply Chains (IJMVSC) Vol.4, No. 3, September 2013.

[5] Ms. Hiral R. Patel, Mr. Amit B. Suthar, Dr. Satyen M. Parikh, "A Proposed Prediction Model for Forecasting the Financial Market Value According to Diversity in Factor" in Int. J. Computer Technology \& Applications, Vol 5 (1),131-135.

[6] K. Senthamarai Kannan, P. Sailapathi Sekar, M.Mohamed Sathik and P. Arumugam, "Financial Stock Market Forecast using Data Mining Techniques" in the International MultiConference of Engineers and Computer Scientists 2010 Vol I,IMECS 2010, March 1719,2010, Hong Kong.ISSN:2078-0966(Online).

[7] Zahid Iqbal, R. Ilyas, W. Shahzad, Z. Mahmood and J. Anjum, " Efficient Machine Learning Techniques for Stock Market Prediction" in Int. Journal of Engineering Research and Applications, ISSN : 2248-9622, Vol. 3, Issue 6, Nov-Dec 2013, pp.855-867.

[8] Marc-André Mittermaye, "Forecasting Intraday Stock Price Trends with Text Mining Techniques" in the 37th Hawaii International Conference on System Sciences 2004.

[9] Ruchi Desai, Prof. Snehal Gandhi, "Stock Market Prediction Using Data Mining" in International Journal of Engineering Development and Research, 2014 IJEDR | Volume 2, Issue 2 | ISSN: 2321-9939.

[10] Prakash Ramani, Dr. P. D. Murarka, "Stock Market Prediction Using Artificial Neural Network" in International Journal of Advanced Research in Computer Science and Software Engineering. ISSN: 2277-128x, Volume 3, Issue 4, April 2013 